\title{
Patenting antibodies
}

\author{
Philip Webber
}

\begin{abstract}
Antibody technology has advanced a long way since the early days of Kohler and Milstein's antibodysecreting murine hybridomas ${ }^{1}$; and although Kohler and Milstein's invention was not patented, patent protection for the new generation of murine, chimeric, humanized and human antibody-based drugs is essential to safeguard their future development.
\end{abstract}

The claims of a patent application must concisely define the matter for which patent protection is sought ${ }^{2}$. In patent applications that relate to antibodies, the claims generally define the antibodies by reference to one or more of the following: the antigen to which the antibody binds; a hybridoma; or the sequence of the antibody polypeptide. The BOX gives some examples of the different ways that antibodies can be claimed.

\section{Antibodies defined by antigens}

Traditionally, the European Patent Office (EPO) has readily granted claims of the following format, particularly if the protein antigen itself satisfies the criterion for patentability: "An antibody which binds specifically to protein X" (BOX, example 1). In such claims, the antibody is being defined indirectly - that is, by reference to the antigen to which it binds. Care needs to be taken, however, to ensure that such claims do not inherently cover known antibodies, particularly if the protein is a member of a family of well-known proteins and antibodies against such proteins are already known. In such circumstances, a claim of the following format should be considered: "An antibody which binds to protein $\mathrm{X}$, but not to protein $\mathrm{Y}$ ", where protein $\mathrm{X}$ is the novel protein and protein $\mathrm{Y}$ is a known one having epitopes in common with the novel protein.

In the US, claims of the above formats are allowable, but the US courts have recently imposed a requirement that the antigen to which the antibodies bind must be a "fully characterized antigen"3.

\section{Antibodies defined by hybridoma}

In cases in which the antigen that the antibody binds to is already known and some antibodies to that antigen have already been publicly disclosed, a general claim to antibodies against that antigen will lack novelty. However, claims to antibodies that are directed to specific epitopes on that antigen might still be possible (assuming that the known antibodies are not directed to those epitopes).

If the invention relates to a specific monoclonal antibody which is produced by a hybridoma, the invention can be claimed by reference to that hybridoma (see BOX, example 2). The question then arises as to how it is possible to describe the hybridoma in the patent application in a manner which will allow the skilled person to put the invention into practice. The answer is to make a deposit of the hybridoma under the Budapest Treaty with an International Depository Authority ${ }^{4}$.

The scope of a claim to a monoclonal antibody defined by a hybridoma will in general be relatively narrow - that is, it will generally only provide protection for the specifically deposited antibody and not other antibodies that are directed to the same epitope. However, deposited hybridomas can also be used to define an epitope on a particular protein and a claim can then be tailored to any antibodies which bind to that epitope ${ }^{5}$.

\section{Antibodies defined by sequence}

With the advent of phage-display libraries and readily available DNA-sequencing apparatus, antibodies are now often defined by reference to specific amino-acid or nucleic-acid sequences (see BOX, example 3 ).

It should be noted, however, that if an antibody is known (for example, an antibody that is produced by a known hybridoma), merely determining the sequence of that antibody will not render that antibody novel — it is still the same (known) chemical entity. However, specific fragments of that known antibody might still be patentable, particularly if they have surprising or unexpected properties.
Frank B. Dehn \& Co., Patent and Trade Mark Attorneys, 179 Queen Victoria Street, London, EC4V 4EL, UK. e-mail:philipw@frankbdehn.com doi: $10.1038 /$ nrd 1963 Published online 20 January 2006

1. Kohler, G. \& Milstein, C. Continuous cultures of fused cells secreting antibody of predefined specificity. Nature 256, 495-497 (1975).

2. Webber, P. M. Protecting your inventions: the patent system. Nature Rev. Drug Discov. 2, 823-830 (2003).

3. Noelle v. Lederman 355 F.3d 1343, 1349 (US Fed. Cir. 2004)

4. Webber, P. M. Patent primer: patenting microorganisms. Nature Rev. Drug Discov. 5, 13 (2006).

5. DakoCytomation Denmark A/S. Dako as monoclonal antibodies against human protein Mcm3, process for their production, and their use. Patent EP 1165615 (2000).

\section{EXAMPLES OF CLAIMS TO ANTIBODIES}

The following are examples of different ways of claiming antibodies.

- Example 1: WO2004/041863

"An anti-IFN $\gamma$ polypeptide comprising at least one anti-IFN $\gamma$ single-domain antibody".

- Example 2: WO03/086456

"An isolated monoclonal antibody or antigen-binding fragments thereof encoded by the clone deposited with the ATCC as PTA-2700"; "The isolated clone deposited with the ATCC as PTA-2700".

- Example 3:WO02/092017

"An antibody or an antigen-binding fragment thereof that specifically binds the capsular polysaccharide of Streptococcus pneumoniae serotype 3 (S. pneumoniae PPS-3), wherein said antibody or fragment comprises a heavy chain amino acid sequence comprising an amino acid sequence selected from the group consisting of:

(a) the amino acid sequence encoded by the DNA sequence set forth in SEQ ID NO: 1; (b) the amino acid sequence of residues 31 to 104 , inclusive, of the amino acid sequence encoded by the DNA sequence set forth in SEQ ID NO: 1 ; and

(c) the CDR1, CDR2 and CDR3 amino acid sequences encoded by the DNA sequence set forth in SEQ ID NO:1".

(In patent applications that refer to nucleotide and/or amino-acid sequences, such sequences are usually listed in a separate section of the patent application called a 'Sequence Listing' in which each sequence is given a unique Sequence Identifier Number — for example, SEQ ID NO: 1, SEQ ID NO: 2 and so on). 